\title{
The Bowati in Kordofan, Sudan: Unique Aquatic Ecosystems of a Non-Nilotic In-Land Delta
}

\author{
Osman Mirghani M. Ali ${ }^{*}{ }^{\circledR}$, Yasin Abadelsalam Elhajaz ${ }^{2}$ \\ ${ }^{1}$ Institute of Environmental Studies, University of Khartoum, Khartoum, Sudan \\ ${ }^{2}$ Africa International University, Khartoum, Sudan \\ Email: *osmirghani@yahoo.co.uk, *osman.mirghani@uofk.edu
}

How to cite this paper: Ali, O.M.M. and Elhajaz, Y.A. (2021) The Bowati in Kordofan, Sudan: Unique Aquatic Ecosystems of a Non-Nilotic In-Land Delta. Journal of Environmental Protection, 12, 1204-1217. https://doi.org/10.4236/jep.2021.1212071

Received: October 22, 2021

Accepted: December 25, 2021

Published: December 28, 2021

Copyright $\odot 2021$ by author(s) and Scientific Research Publishing Inc. This work is licensed under the Creative Commons Attribution International License (CC BY 4.0).

http://creativecommons.org/licenses/by/4.0/

(c) (i) Open Access

\begin{abstract}
This paper describes the unique in-land, non-Nilotic delta of Wadi El Galla, a seasonal water course which originates in the Nuba Mountains of Kordofan region and terminates in a chain of small ponds each known locally as a Bouta (pl Bowati). The Bowati are inhabited by a community of aquatic plants forming a wide spectrum ranging from small true (Euophytes) to large woody trees. The euophytes encountered were grouped into six categories. The freefloating species were represented by the small Lemna purpusilla Torr. and the larger Pistia stratiotes $\mathrm{L}$. while only one submerged species was found: Ottelia alismoides (Planch.) Welp. One suspended species was found, Utricularia stellaris L. F. Three species of the floating-leaved plants were encountered namely, Nymphaea lotus L., N. micrantha Guill. \& Perrott and Nymphoides nilotica (Kotschy \& Peyr.) Léonard. The emergent Limnophyton obtusifolium (L.) Miq. was very prominent in all the Bowat constituting with $N$. lotus the two dominant species. Trailing from the Bouta edge and forming thick mats on the open water is Neptunia oleracea Lour., a member of the Fabaceae family. Within these euophytes and towering to over ten meters is the woody tree Mitragyna inermis Kuntze. Some of herbaceous plants are a source of food for the local community such as the bulbils of Nymphaea micrantha. These meagrely studied ecosystems are under threat from natural and anthropogenic factors. The former are the recurrent drought, climate change, and the latter are due to urbanization, overexploitation and oil activities. There is an urgent need for delineating and mapping the geomorphology, drainage patterns of Al Muglad in-land delta as well as the number and sites of the Bowati. The taxonomy of the aquatic species, their nutritive and medicinal values are other areas of research. Within such a context, a concerted national and international endeavour is called for to conserve these unique ecosystems and conceivably, declaring them as protected sites.
\end{abstract}




\section{Keywords}

In-Land Delta, Seasonal Ponds, Bowati, Aquatic Macrophytes

\section{Introduction}

The area of study is in the north western part of the Muglad Basin in West Kordofan State (Figure 1). The Muglad Basin is a large rift basin in Northern Africa. The basin is situated within southern Sudan and South Sudan, and it covers an area of approximately 120,000 square kilometres across the two nations. It contains several hydrocarbon accumulations of various sizes, the largest of which are the Heglig and Unity oil fields [1]. The Muglad basin is the largest known rift in the Sudan interior. It trends northwest-southeast and covers about 120,000 $\mathrm{km}^{2}$. The basin is around $800 \mathrm{~km}$ in length and $200 \mathrm{~km}$ in width [2]. Khor Abu Habil terminates in a delta in the White Nile. Khor Abu Habil has a common water shed with Wadi El Galla which flows southwest wards while Khor Abu Habil flows northeast wards. Wadi El Galla flows from the Nuba mountain near El Dilling town to the south west direction and terminates in Muglad town in the form of an inland delta constituted of a chain of small ponds each known locally as a Bouta (pl Bowati). This delta has not been previously recorded in the literature of the geology and geomorphology of the Republic of the Sudan. The delta comprises one of the unique, least studied aquatic ecosystems hosting a remarkable floral community.

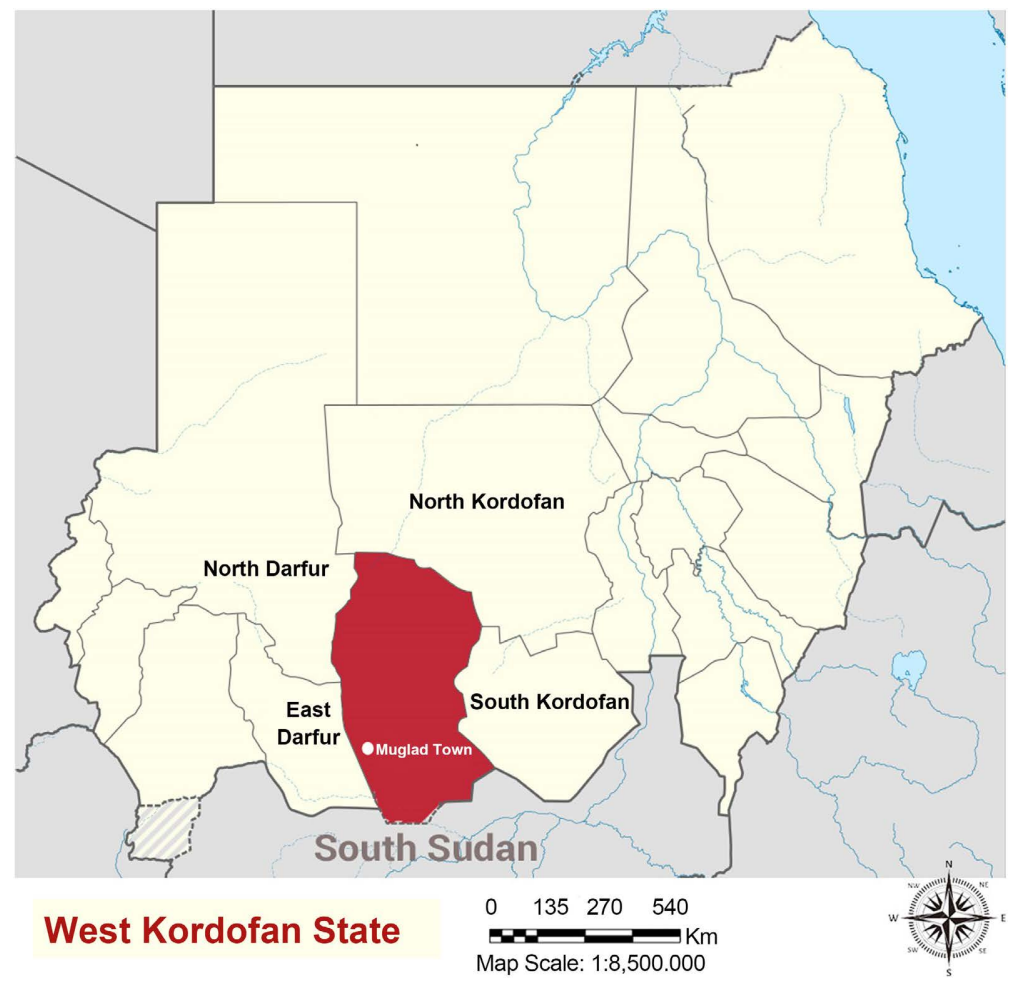

Figure 1. West Kordofan State. 


\section{Wadi El Galla System}

\subsection{Wadi El Galla Catchment}

The catchment area of Wadi El Galla is dominated by the Basement Complex rocks. These rocks consist of igneous and metamorphic assemblage which is made up of folded gneiss and schist of sedimentary and volcanic origin with foliated granites. Synorogenic or late orogenic granite emplacement and basic and ultra-basic bodies also occur [3]. The formation unconformable overlies the Basement complex rocks. It is mainly composed of multi layers of sandstone and mudstone sediments of non-marine origin [3]. On the downstream part of Wadi El Galla, the Umm Rawaba formation appears. This formation is composed of ill-sorted fluvial continental deposits made up of sand, clay and gravel. It lies unconformable on the Nubian Sandstone formation [4].

The drainage system of Wadi El Galla is shown in Figure 2. The geomorphology of the study area is dominated by a flatland surface which is covered by silty soils in the Muglad area and red sandy soils in the northern part of the study area. The only water course is Wadi El Galla which originates in the Nuba Mountains and terminates in a series of sandy soils. The drainage system of Wadi El Galla is mainly rectangular in the upper reaches of the Wadi. This indicates that the course of the wadi is structurally controlled by lineaments (faults, joints and fractures). In the downstream side the wadi has established a flood plain with a significant meandering system.

According to El Tayeb [5], the average annual amount of water flow in Wadi El Galla is estimated as 73 million cubic meters. This amount of water is mainly utilized for domestic uses and animal watering. The effective catchment of Wadi El Ghalla is estimated to be 10,700 square kilometres.

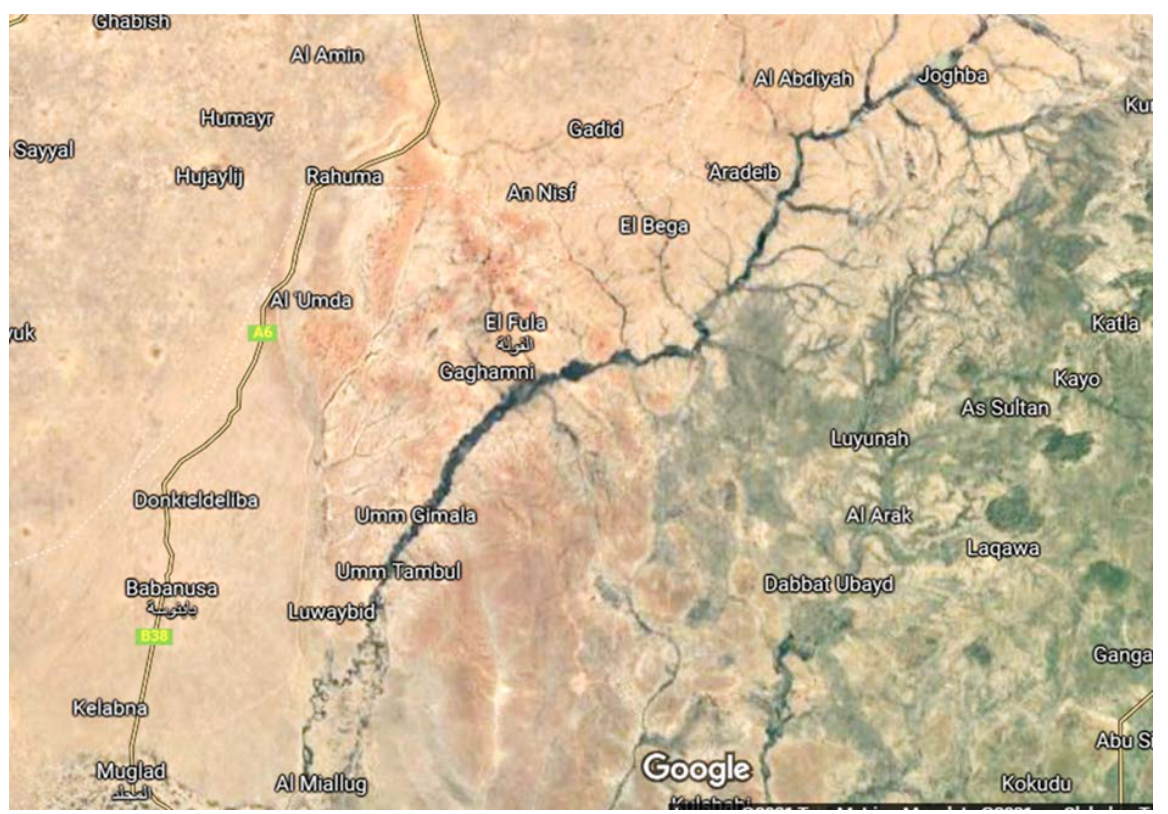

Figure 2. The drainage system of Wadi El Galla. 
The area falls in a semi-humid tropical climate zone. The rainy season extends from May to October with peak values in August when the ITCZ is usually at its extreme northern position. The average mean maximum temperature over the area is $39.0^{\circ} \mathrm{C}$ while minimum temperatures are in the range of $24.6^{\circ} \mathrm{C}-26.1^{\circ} \mathrm{C}$ in the cool months of January/February.

\subsection{The Bowati of Wadi El Galla}

Wadi El Galla flows sluggishly southward in a shallow valley skirting the edge of the sandy pediplain around AnNuoud town. The Wadi disperses in a delta (Figure 3), known as Al Muglad (after the reddish sandy clay soil which predominates in the area). Within and around Al Muglad Wadi El Galla forms a chain of small ponds each known known locally as a Bouta (pl Bowati). These Bowati hold water for almost a year and are utilized by the locals as sources of water (Figure 4). They also constitute a special ecosystem rich with aquatic plants (Figure 5).

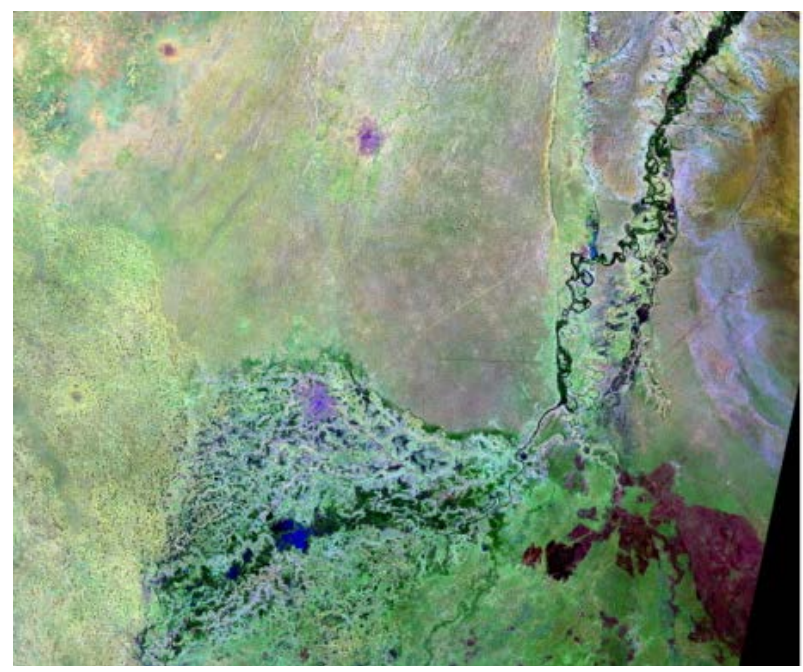

Figure 3. The inland delta of Wadi El Galla.

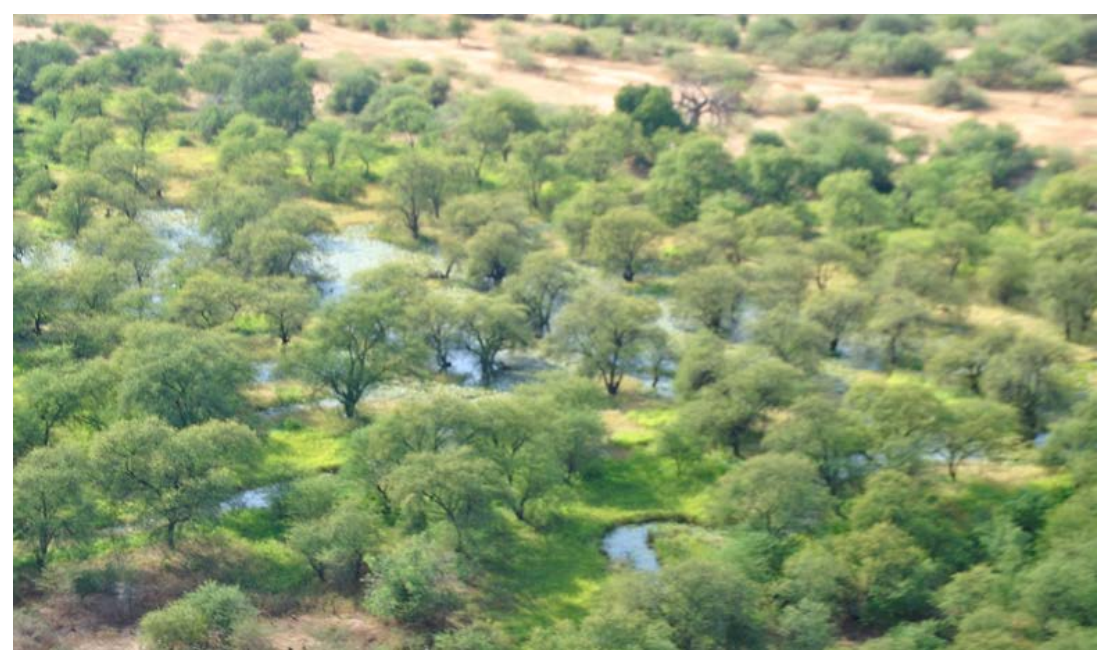

Figure 4. An aerial view of one of the Bowati near Muglad town. 


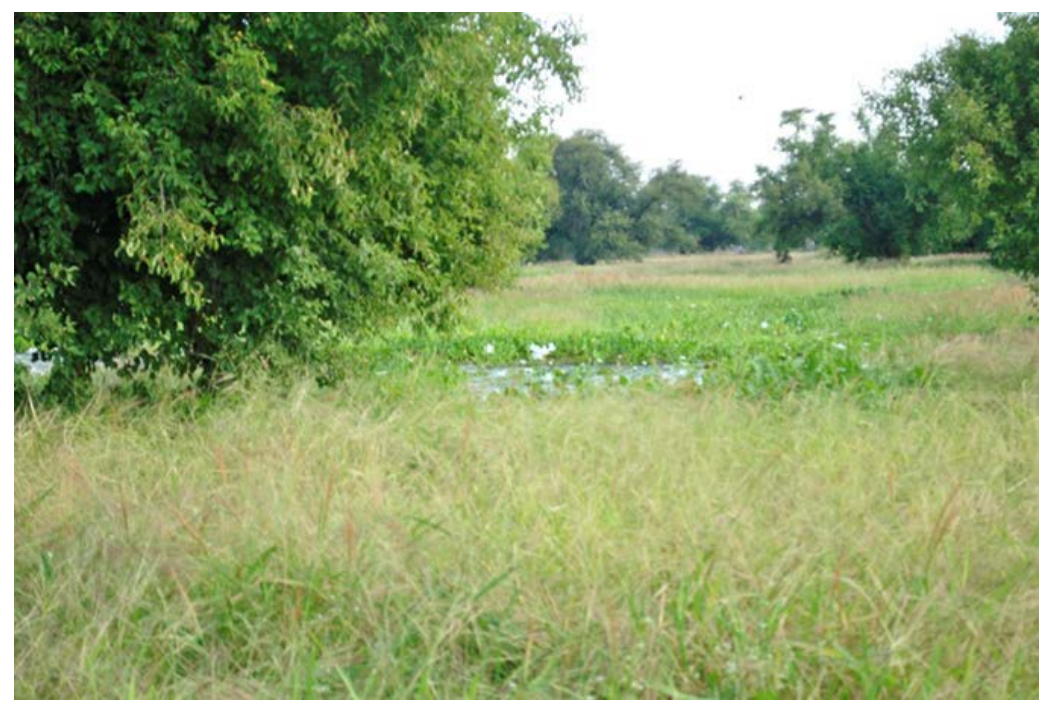

Figure 5. Typical scene of a Bouta.

\subsection{The Aquatic Macrophytes in the Bowati of Wadi El Galla}

A rich community of aquatic macrophytes has been encountered within the Bowati of Al Muglad. The majority are Angiosperms with one member from the Pteridophytes. Within the flowering plants both woody and herbaceous members are encountered. The former is represented by the remarkable Mitragyna inermis Kuntz of the family Rubiaceae. The tree-known locally as Ingatu or Umm Gato is reported to grow on soils that are inundated for several months of the year [6]. It has a dense, wide crown growing up to 16 metres tall. The bole is up to $60 \mathrm{~cm}$ in diameter with branches usually forming from low down (Figure 6). Its presence ranges from Senegal to Sudan and south to Zaire. Mitragyna inermis, with Bridelia ferruginea and Combretum glutinosum, have their popular use in the treatment of bacterial, fungal, malaria and viral infections and cardiovascular problems in West Africa, been validated [7]. In Sudan the use of Mitragyna inermis and Terminalia laxiflora parks and the leaves of Balanites aegyptiaca were reported for the treatment of malaria [8].

Apart from Mitragyna inermis, the species encountered within the Bowat are true aquatic macrophytes (euophytes) exhibiting fascinating life forms. There are six types of life forms: free floating, rooted submerged-leaved, suspended, submersed floating-leaved, emergent and trailing on water surface from edge of the Bouta. suspended aquatic carnivorous plant

\subsubsection{Free Floating}

\section{Araceae:}

Pistia stratiotes L. (Figure 7). The plant was encountered in restricted sites within the area.

Lemna perpusilla Torr.

The duckweeds and related genera of the duckweed family (Lemnaceae) are the smallest flowering plants known. These tiny plants form a carpet -like cover. Each plant consists of a single flat leaf that floats on the surface of still waters 
such as ponds and lakes (Figure 8).

The rapid growth of duckweeds finds application in bioremediation of polluted waters, in municipal wastewater treatment [9] and as test organisms for environmental studies.

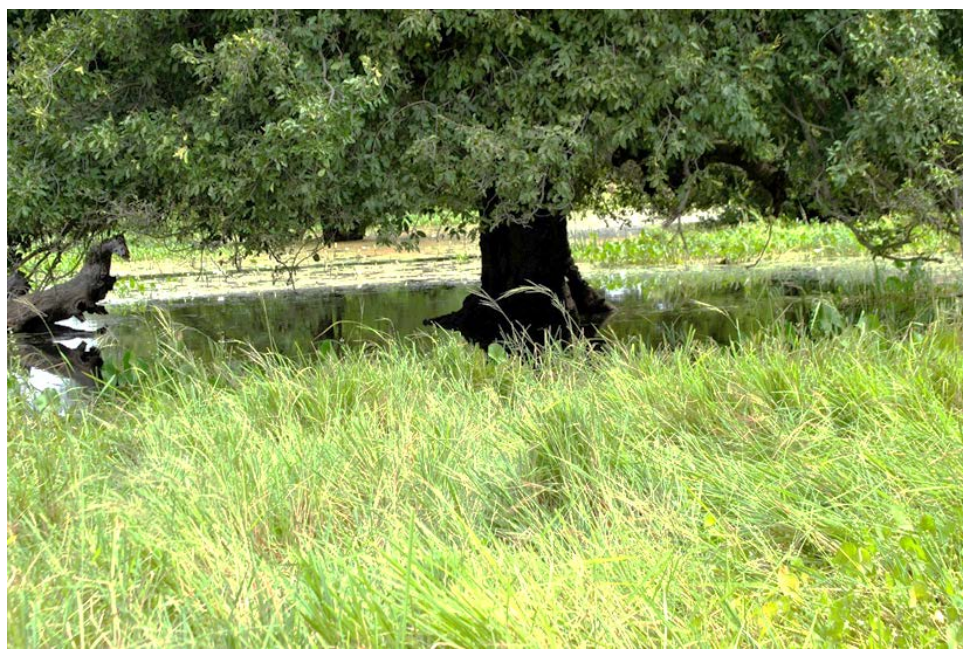

Figure 6. A Bouta in Al Muglad town showing the woody tree Mitragyna inermis Kuntze.

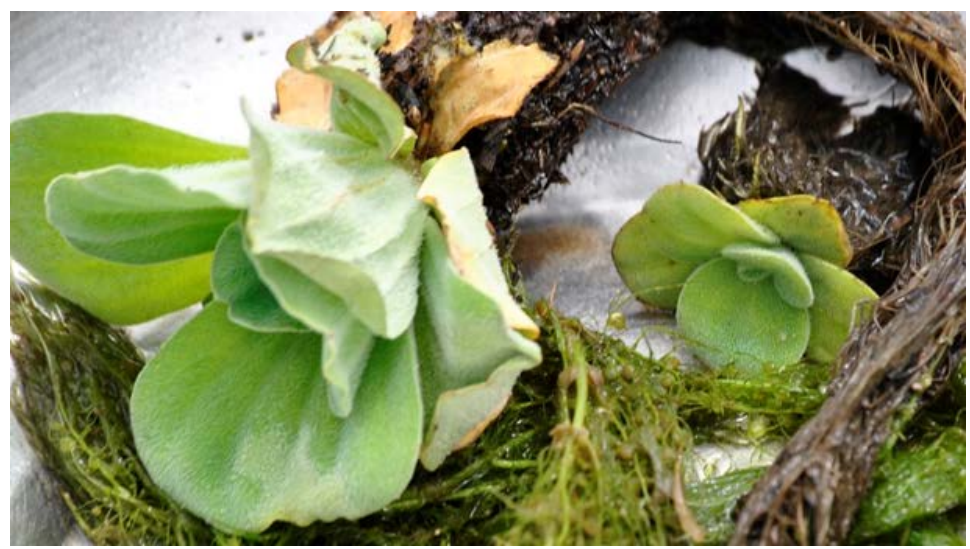

Figure 7. Pistia stratiotes, possibly entangled with Utricularia spp.

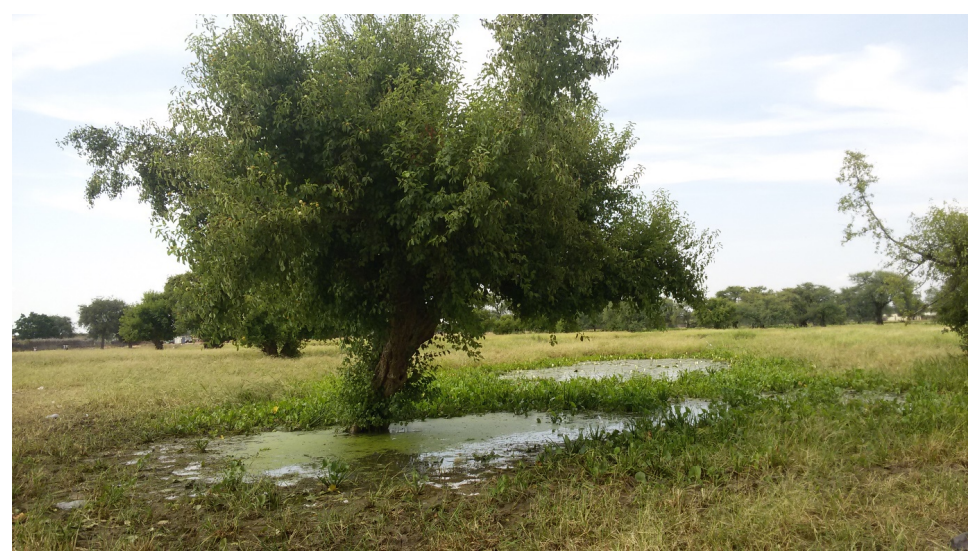

(a) 


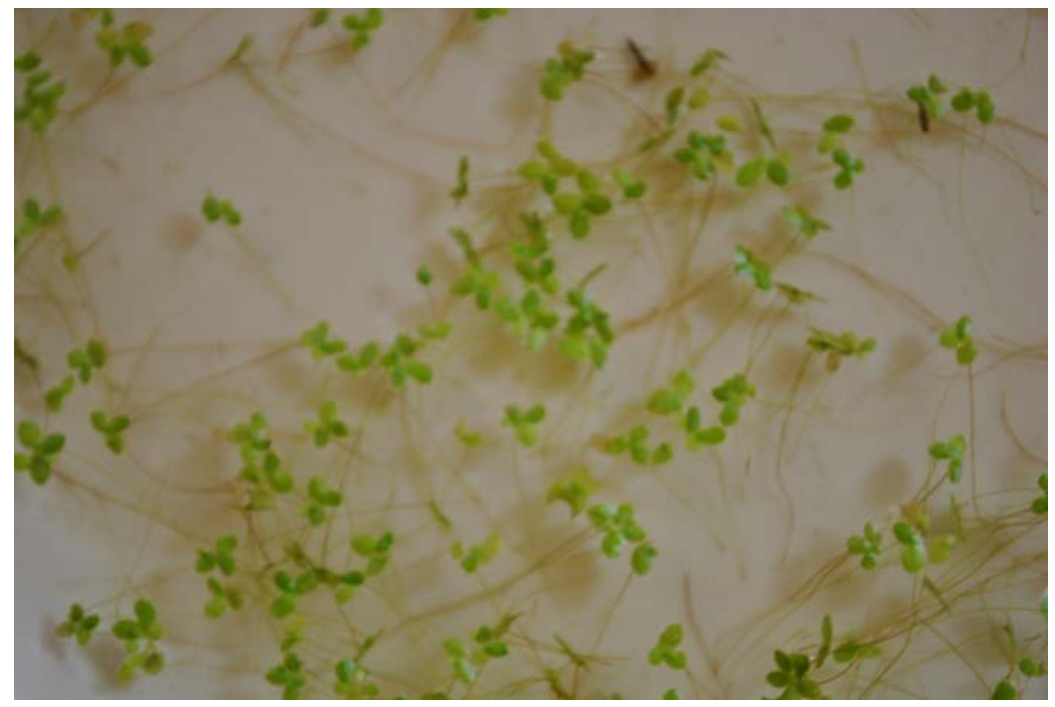

(b)

Figure 8. (a) Mitragyna inermis tree in a Bouta with the floating Lemna sp. forming a mat on the water surface; (b) Lemna perpusilla Torr.

\subsubsection{Suspended}

\section{Lentibulariaceae:}

The Bladderworts belong to the most recently evolved group of carnivorous plants. Within the Bowati Utricularia stellaris L.f. was encountered suspended within the water. It was distinguished with its yellow flowers and solitary traps for capturing small organisms (Figure 9).

\subsubsection{Rooted Submersed Leaves}

\section{Hydrocharitaceae:}

Ottelia ulvifolia (Planch.) Walp.

O. ulvifloia members were encountered in Al Muglad Bowati exhibiting their solitary and flowers blossoming on the surface of the water (Figure 10).

\subsubsection{Rooted Floating-Leaved \\ Nymphaeaceae}

1) Nymphaea lotus $L$

The Egyptian white waterlily, with its toothed floating leaves (Figure 11) is found associated with the other macrophytes such as Ottelia ulvifolia and Limnophyton obtusifolium.

2) Nymphaea micrantha Guill. \& Perrott.

$N$. micrantha is also encountered in all the Bowat distinguished by its entire or slightly undulate leave margin (Figure 12). The petioles bear a cluster of bulbils These are collected, roasted and eaten by the locals (Figure 13).

\section{Menyanthaceae:}

Nympoides nilotica (Kotschy \& Peyr.) Léonard

Nymphoides, or floatingheart, are aquatic plants with submerged roots and floating leaves that hold the small flowers above the water surface (Figure 14). 


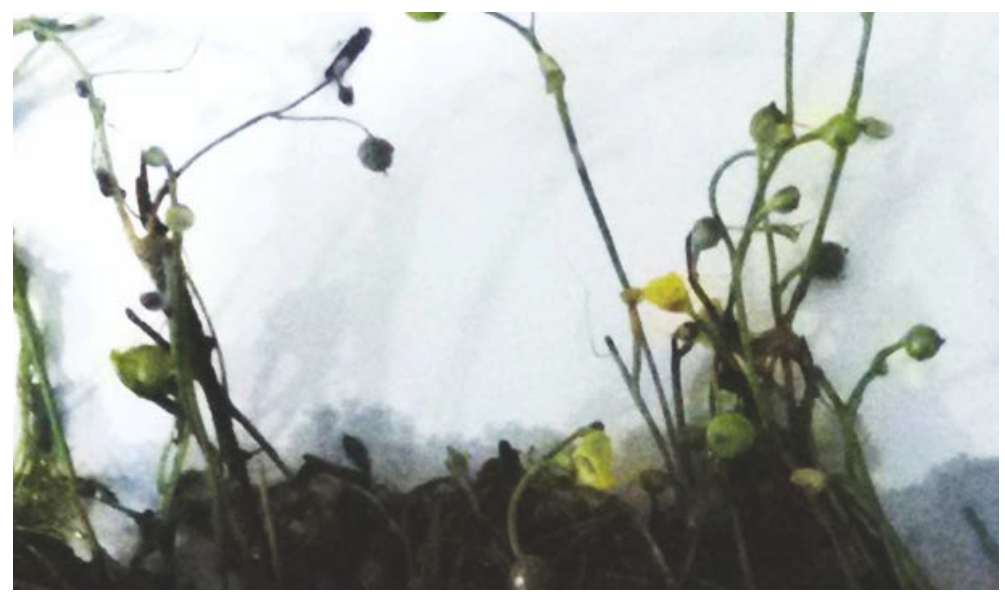

Figure 9. Utricularia stellaris L.f with solitary traps and yellow flowers.

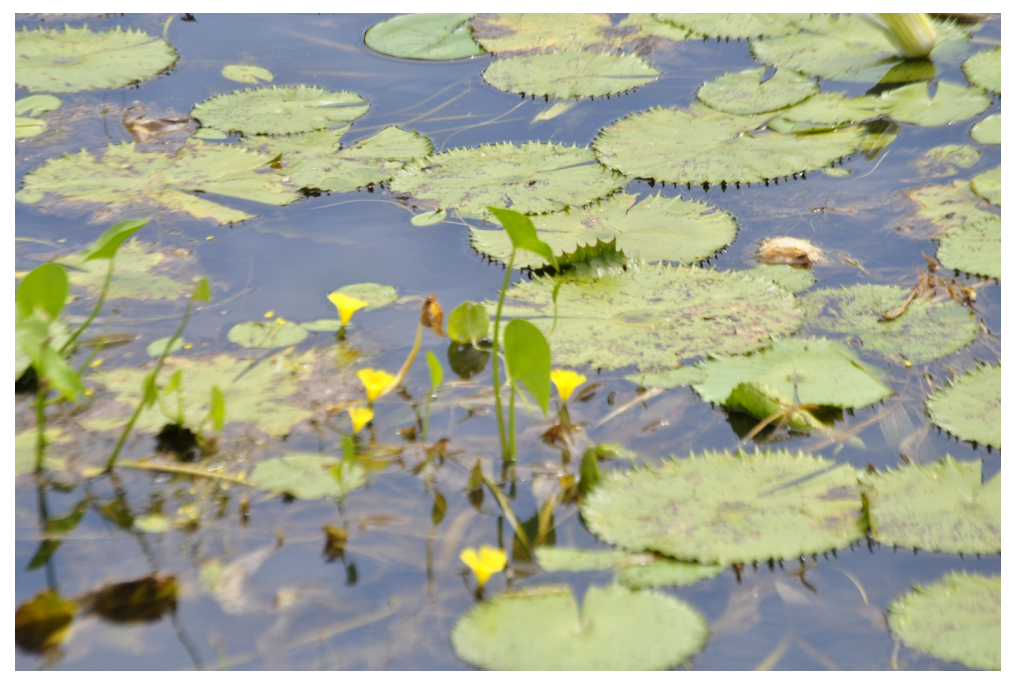

Figure 10. The yellow-flowered Ottelia ulvifolia (Planch.) Walp.

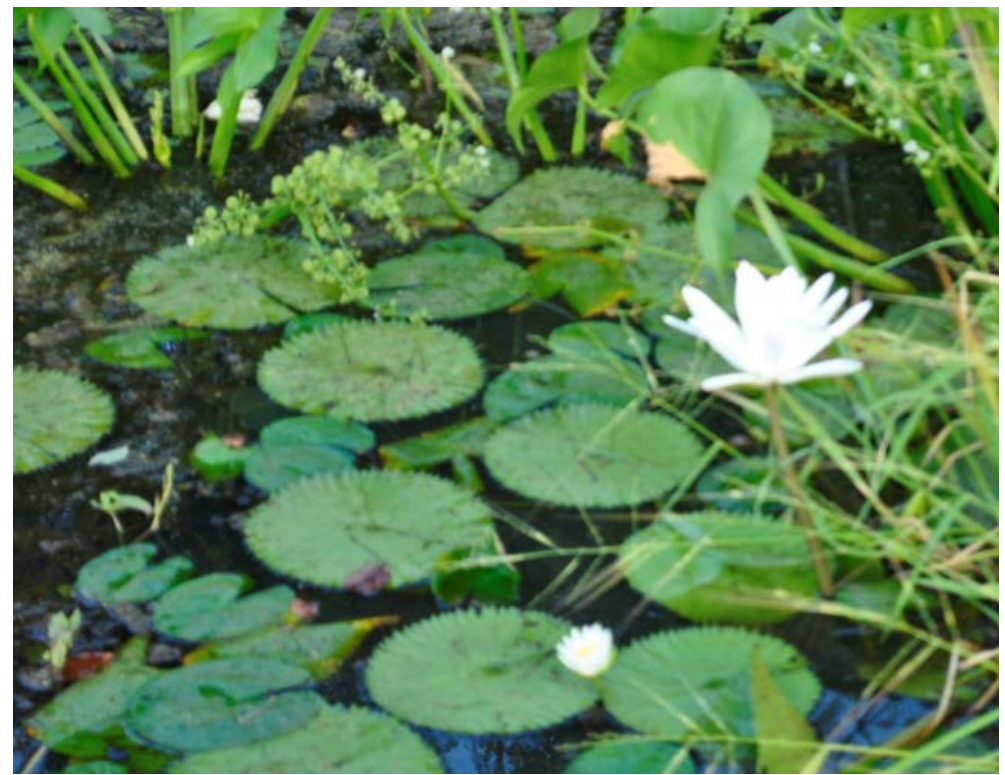

Figure 11. Nymphaea lotus L. 


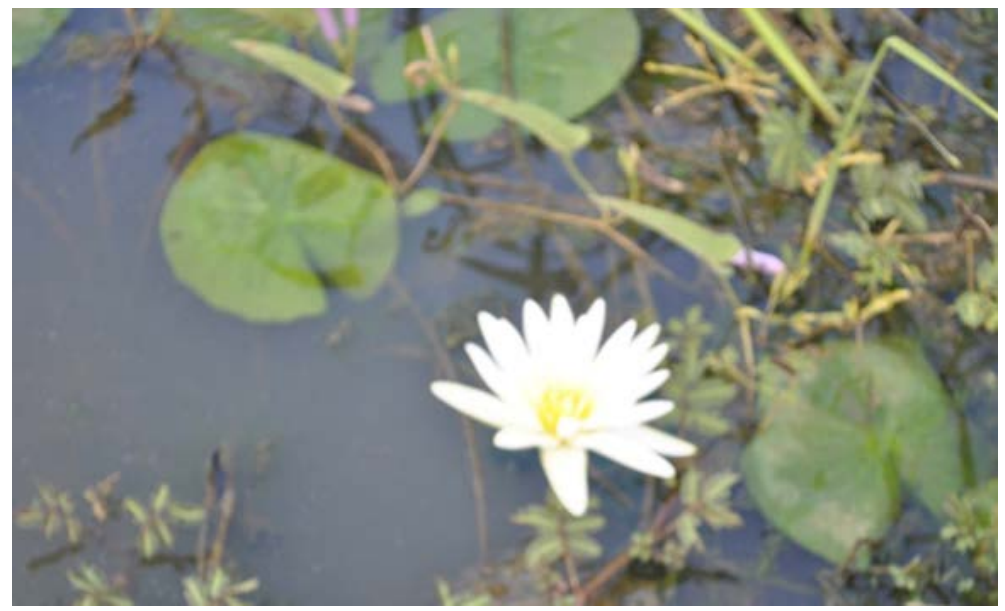

Figure 12. Nymphaea micrantha Guill. \&Perr.

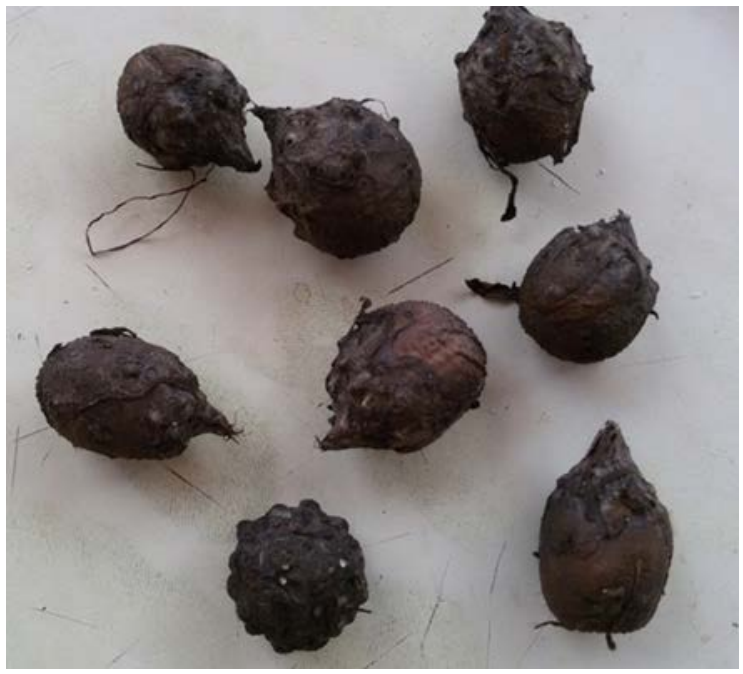

Figure 13. Roasted bulbils of $N$. micrantha.

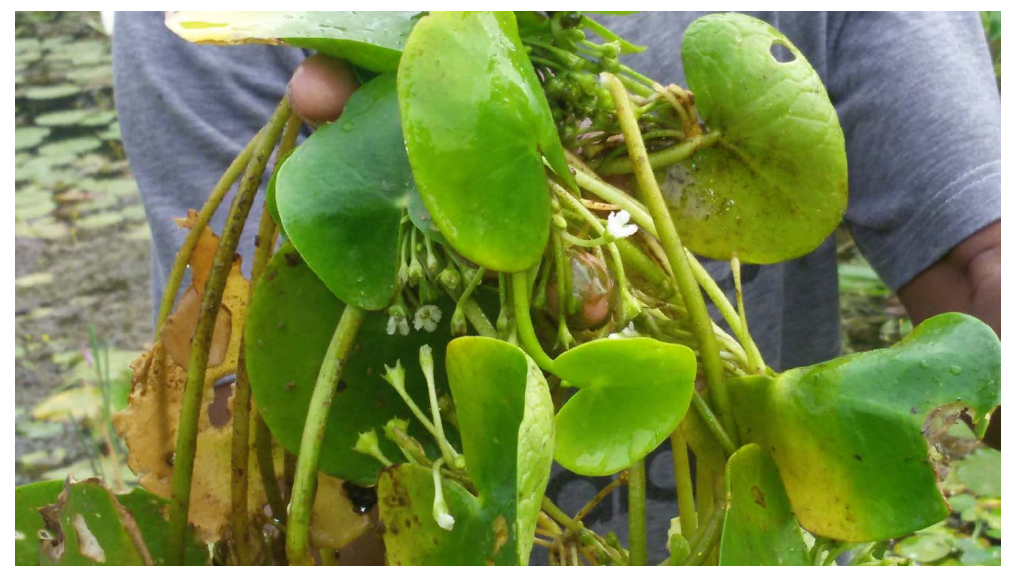

Figure 14. Nympoides nilotica (Kotschy \& Peyr.) Léonard.

\subsubsection{Emergent}

Within this group of macrophytes two species were encountered belonging to two different families: 


\section{Alismataceae:}

This family is represented by Limnophyton obtusifolium (L.) Miq. (Figure 15), growing in dense clusters among the other floating and emergent plants.

\section{Poaceae:}

The Poaceae family was represented by the perennial wild rice Oryza longistaminata A. Chev. \& Roehrich (Figure 16).

\subsubsection{Trailing on Water Surface}

Two species of two different families were encountered within the Muglad Bowati, namely Ipomoea aquatica Forssk. and Neptunia oleracea Lour. The former belongs to the family Convolvulaceae while the other belongs to the family Fabaceae. Unlike $I$. aquatica which is a common herb in most aquatic habitats in Sudan, $N$. Oleracea, known as water mimosa, is rarely reported in the literature. It was found growing prostrate and floating on the water in several Muglad Bowati (Figure 17) sometimes forming a wide mat in open surfaces (Figure 18). The trailing stem produces spongy, fibrous roots between the nodes, while the inflorescence, a solitary axillary spike, erects over the water surface (Figure 19).

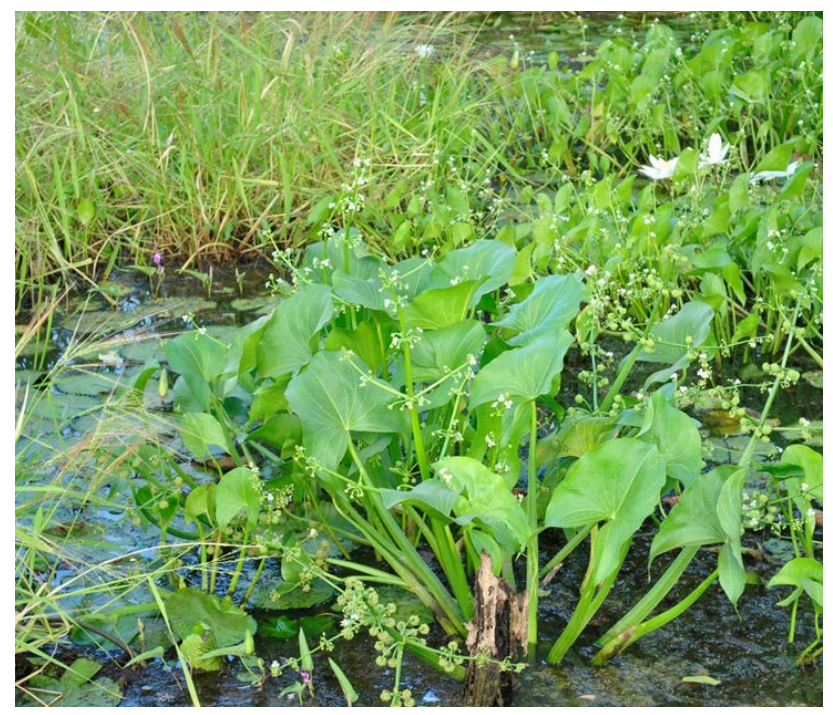

Figure 15. Limnophyton obtusifolium (L.) Miq.

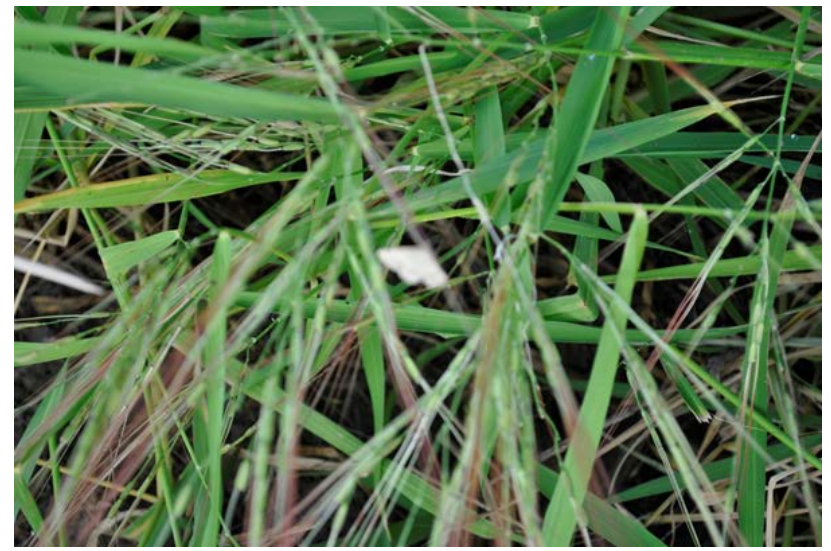

Figure 16. Oryza longistaminata (perennial wild rice). 


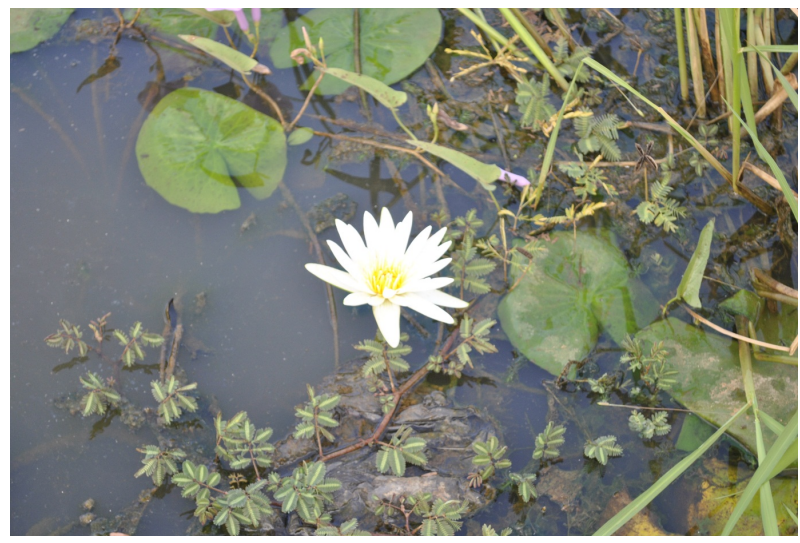

Figure 17. Neptunia oleracea growing prostrate and floating on the water in several Muglad Bowati.

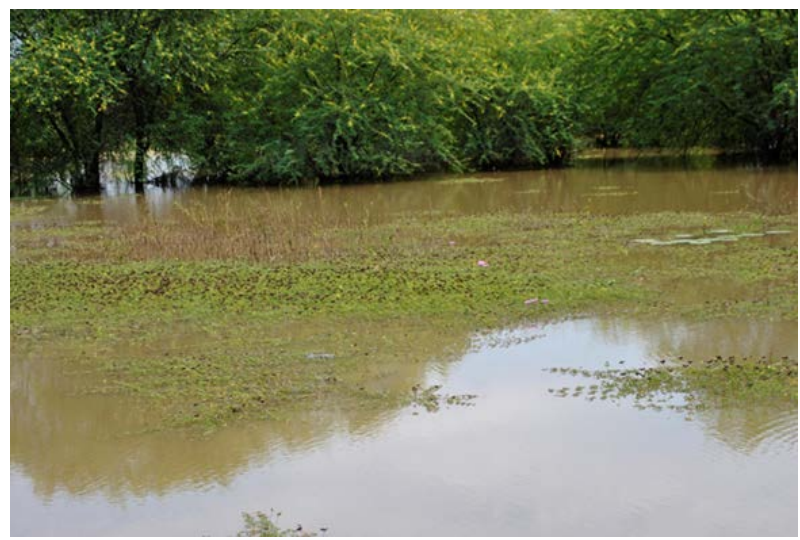

Figure 18. A mat of Neptunia oleracea trailing from the water edge.

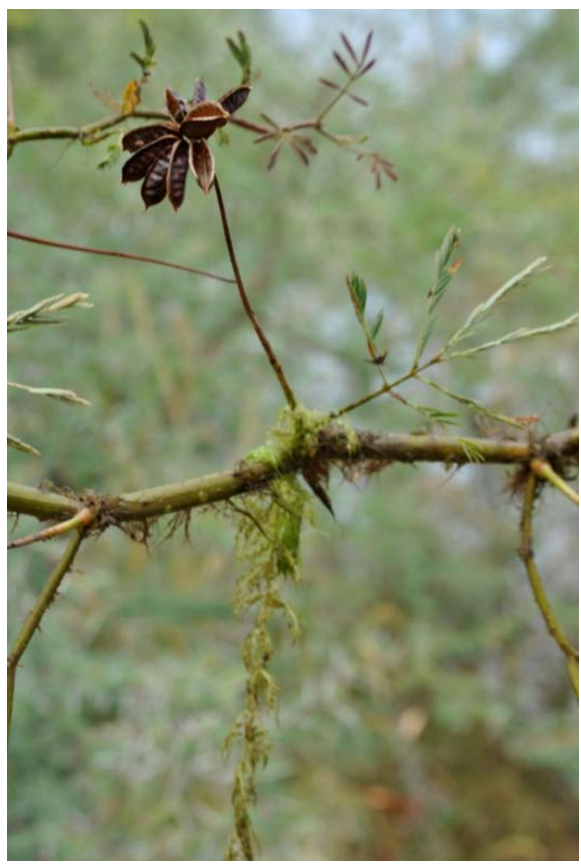

Figure 19. Neptunia oleracea: Fibrous roots at the nodes and solitary inflorescence erecting over the water surface. 
The fruit is a legume, green when unripe and brown when mature, splitting along both sides.

\section{Pteridophyte: ferns}

\section{Marsileaceae:}

Marsilea gibba A. Braun: Rooted, aquatic herb with floating leaves (Figure 20).

\section{Discussion}

The inland delta of Wadi El Galla is a remarkable formation from both geomorphological and biological aspects. It is acclaimed as being, so far, the only non-Nilotic inland delta in Sudan. And as such, it is least mentioned and studied. The seasonal ponds (Bowati) within this delta portray a unique cluster of

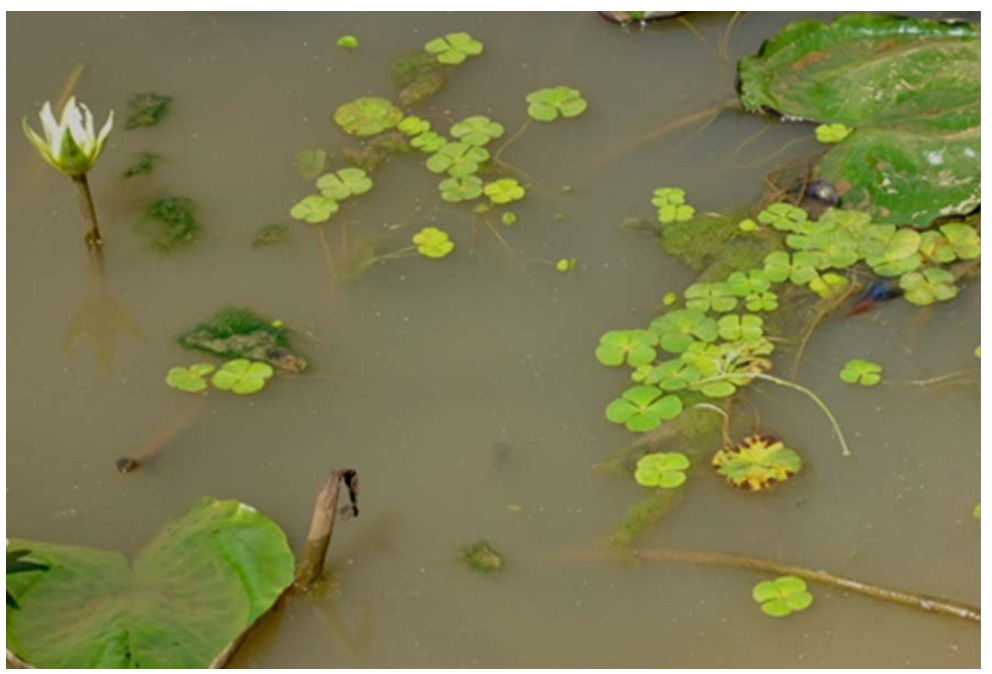

Figure 20. Marsilea gibba A. Braun.

List of species encountered in the Bowati of Muglad.

\begin{tabular}{ccc}
\hline No. & Family & Scientific name \\
\hline 1 & Rubiaceae & Mitragyna inermis Kuntze \\
2 & Araceae & Pistia stratiotes L. \\
3 & Araceae & Lemna perpusilla Torr. \\
4 & Lentibulariaceae & Utricularia stellaris L. f. \\
5 & Hydrocharitaceae & Ottelia ulvifolia (Planch.) Welp \\
6 & Nymphaceae & Nymphaea lotus L. \\
7 & Nymphaceae & Nymphaea micrantha Guill. \& Perrott. \\
8 & Menyanthaceae & Nympoides nilotica Kotschy \& Peyr. Léonard \\
9 & Alismataceae & Limnophyton obtusifolium (L.) Miq. \\
10 & Poaceae & Oryza longistaminata A. Char.\& R \\
11 & Fabaceae & Neptunia oleracea Laour. \\
12 & Marsileaceae & Marsilea gibba A. Braun \\
\hline
\end{tabular}


aquatic ecosystems, rich in aquatic macrophytes. Twelve species were reported belonging to ten families. However, with time and accessibility constraints, this list is not inclusive and other species are most probably had been overlooked. This information in this article is a significant contribution to previous, meagre studies on freshwater aquatic macrophytes [10].

The Muglad Bowati ecosystems are under threat from both natural and anthropogenic factors. The former is the recurrent drought and climate change, while the latter is due to oil activities, urbanization, and overexploitation. The repercussions of the anthropogenic factors on these unique wetlands are imminent.

\section{Recommendations}

The following measures are recommended:

1) Geological, geomorphological as well as hydrological investigations are required to study Al Muglad in-land delta.

2) A clear national vision towards the aquatic habitats in the Sudan needs to be developed.

3) Detailed limnological studies are needed for the biotic and abiotic features of Al Muglad Bowati.

4) Collaboration between Sudan and the regional and international organizations and institutions such as the Royal Botanic Gardens, Kew, IUCN and IHE will be a great asset.

5) It is proposed that Al Muglad in-land delta and its Bowati systems to be declared as protected sites.

\section{Conclusions}

Wadi El Galla is a seasonal water course originating in the Nuba Mountains of Kordofan region and terminates in an inland delta forming a chain of small ponds each locally known as a Bouta (pl Bowati). The Bowati are inhabited by a community of aquatic plants embracing six growth forms: free-floating, submerged, suspended, floating-leaved, emergent and trailing from the Bouta edge. Some of herbaceous plants are a source of food for the local community such as the bulbils of Nymphaea micrantha.

These meagrely studied ecosystems are under threat from natural and anthropogenic factors. The former are the recurrent drought, climate change, and the latter are urbanization, overexploitation, and oil activities.

There is a need for detailed geomorphological and hydrological studies of $\mathrm{Al}$ Muglad in-land delta. Detailed limnological studies are also needed for the biotic and abiotic features of Al Muglad Bowati.

\section{Acknowledgements}

The authors sincerely acknowledge the help of the late Mr. Mohamed F. Idris for identification of some of the plants in the article. 


\section{Conflicts of Interest}

The authors declare no conflicts of interest regarding the publication of this paper.

\section{References}

[1] NPA Satellite Mapping (2008) "Sudan-Muglad Basin".

[2] Mohamed, A.Y., Pearsons, M.J., Ashcroft, W.A., Iliffe, W.A. and Whiteman, A.J. (1999) Modelling Petroleum Generation in the Southern Muglad Rift Basin, Sudan. $A A P G, 83,1943-1964$.

[3] Vail, J.R. (1978) Outline of the Geology and Mineral Resources of the Democratic Republic of Sudan and Adjacent Areas. Geol and Mineral Resources No. 49, Instit. Geolog. Sc., London.

[4] Whiteman, A.J. (1971) The Geology of the Sudan. Clarendon, Oxford, 299 p.

[5] El Tayeb, M.E. (1982) Wadis in Sudan. In: Salih and Khadam (Eds.), Water Resources in the Sudan. National Council for Research.

[6] Burkill, H.M. (2004) The Useful Plants of West Tropical Africa. Vol. 4. Royal Botanic Gardens, Kew, 969 p.

[7] Alowanou, G., Pascal, A., Erick, Azando, V.B., Dedehou, V.N. and Daga, F.D. (2015) A Review of Bridelia ferruginea, Combretum glutinosum and Mitragina inermis Plants Used in Zootherapeutic Remedies in West Africa: Historical Origins, Current Uses and Implications for Conservation. Journal of Applied Biosciences, 87, 80038014. https://doi.org/10.4314/jab.v87i1.4

[8] Doka, I.G. and Yagi, S. (2009) Ethnobotanical Survey of Medicinal Plants in West Kordofan (Western Sudan). Ehnobotanical Leaflets, 13, 1409-1416.

[9] Gatidou, G., Stasinakis, A.A. and Iatrou, E. (2015) Assessing Single and Joint Toxicity of Three Phenylurea Herbicides Using Lemna minor and Vibrio fischeri Bioassays. Chemosphere, 119, 69-74. https://doi.org/10.1016/j.chemosphere.2014.04.030

[10] Ali, O.M. (2009) Aquatic Plants of the Sudan. In: Dumont, H.J., Ed., The Nile. Monographiae Biologicae, Vol. 89, Springer, Dordrecht.

https://doi.org/10.1007/978-1-4020-9726-3 23 